\title{
Job Flows And Plant Size Dynamics: Traditional Measures and Alternative Econometric Techniques
}

\author{
Pietro Garibaldi \\ (International Monetary Fund) *
}

December 11, 1996

\begin{abstract}
This paper measures the relation between job flows and establishment size applying econometric techniques best suited for analysing the dynamics of large cross-section. Using a balanced panel from the Mexican Manufacturing sector, it shows that, in line with cross-country evidence, initially small firms create proportionally more jobs than large firms. Since these results suffer from regression toward the mean, the paper applies an alternative technique and it does not find long-run tendency of small establishment to converge toward the mean. Furthermore, it shows how cross-sectional dynamics varies across industries and how it is linked to gross and net flows in each sector. We observe convergence to the mean in relatively stable sectors and asymmetric dynamic behaviour between expanding and declining industries.
\end{abstract}

Keywords: Job Flows, Firm Size Dynamics, Regression to the Mean.

Address:

Pietro Garibaldi

International Monetary Fund

20431 Washington, D.C.

U.S.A.

internet: pgaribaldi@imf.org

\footnotetext{
*I am indebted to Danny Quah for introducing me to most of the concepts of this paper. I have benefitted from useful conversations with Ana Lamo, Chris Pissarides, Dieter Guffens, Claudio Michelacci and Lia Pacelli.
} 


\section{Introduction}

In the last few years, much of the discussion on the labour market focused on the process of job formation and destruction and great emphasis has been given to the relation between job flows and firm size, both in the policy debate (OECD 1994) and among academic scholars (Davis et al. 1995).

If we define firm size as employment in a base year, across countries, two statistical regularities hold. Job creation and destruction are substantially greater among small firms and net employment changes are a decreasing function of establishment size. These findings stimulated the policy emphasis on the crucial role of small firms in the process of job formation. Unfortunately, several statistical problems are associated with these findings. Among others, Davis et al. $(1994 ; 1995)$ point out the regression fallacy associated with the relationship between net employment changes and firm size and they suggest an alternative approach based on the notion of long run optimal size. When firm size is measured as the average employment across all years in the sample, Davis et al. show that in the U.S. manufacturing sector there is no clear relationship between net job creation and firm size.

In this paper I firstly assess the traditional measures and I argue that any definition of firm size that arbitrary forces each unit in the sample into a pre-defined size category, will ignore the flows of jobs between size categories. Furthermore, when firm size is defined as the average employment across all years in the sample, a positive relationship between firm size and net job creation may simply indicate that initially smaller firms created jobs throughout the period and end up relatively larger.

Clearly, to estimate properly firm size convergence avoiding the regression fallacy and to follow accurately employers between size categories, it is necessary to apply an alternative econometric technique. Fortunately, methodology for this purpose has recently been introduced by Quah (1993a; 1993b) in the context of economic growth, and applied by Lamo and Koopmans (1995) in the study of plant distribution in the Chemical sector and by Konings (1995) in a paper that studies the evolution of plant size in the British manufacturing sector. Using a balanced panel for the Mexican manufacturing sector, I show how conventional results may change when firm size dynamics is estimated non parametrically. Overall, I find no evidence of small firms systematically creating more jobs than larger firms and, thus, no evidence of convergence to the mean for the sample as a whole. I show how distribution dynamics varies across industries and how it is linked to gross and net flows in each sector. I observe convergence to the mean in relatively stable sectors and asymmetric dynamic 
behaviour between expanding and declining industries.

The paper proceeds as follows. Section (2) briefly describes the data and measures job flows for the Mexican manufacturing industry. Section (3) assesses the traditional methodology for studying the relationship between job flows and establishment size. Section (4) describes an alternative technique based on a direct estimate of the dynamics of the entire firm-size distribution. Section (5) applies the methodology at the aggregate and at the industry level while section (6) briefly summarizes and concludes the paper.

\section{Measurement Criteria}

\subsection{The Data}

The dataset I will use is a panel of 2021 continuing establishment over the period of 1984 to 1990 ( 7 years). The source of data are administrative records of the "Annual Industrial Survey" of the Mexican manufacturing industry. On average, it covers between 70 and 80 percent of the industry in terms of production and employment. The average establishment size in the sample is 220 employees and entry and exit of establishments are not observed. Each establishment is assigned to an industry at the level of the Mexican Census classification. These industries have been aggregated to the "Raga" level, which corresponds to the classification used in the Input Output table of 1985. The number of industries is 47, which can be aggregated to 10 , as I do in section 5. Within the sample, large establishments correspond to the manufacturing population while small firms are randomly sampled. The under-representation of small firms may apparently be a problem for the issue of this paper, but I do not see why the results of this paper should be affected by the fact that smaller establishments are randomly sampled. I will come back to this point later in the paper.

\subsection{Notation and Definitions}

Let $x_{i t}$ be the size of establishment $i$ at time $t$, which, as we outline in the next section, can be measured as employment at time $t$, as employment between $t$ and $t+1$ or as average employment in all years in the sample. The growth rate of establishment $i$ time $t, g_{i t}$, is then defined as

$$
g_{i t}=\frac{n_{i t}-n_{i t-1}}{x_{i t}}
$$

where $n_{i t}$ and $n_{i t-1}$ are employment for establishment $i$ at time $t$ and $t-1$ respectively. If $x_{i t}$ is measured as the average employment between $t$ and $t-1,(1)$ is similar to the growth 
rate used by Davis- Haltiwanger (1990) and (1992), with deaths (births) corresponding to the left (right) endpoint. In the present paper the interval will be somewhat smaller since we do not observe deaths and births. The gross job creation and destruction rate are related to the size weighted frequency distribution of firm growth rates in the following way. Let job creation in sector $j$ at time $t$ be defined as

$$
J C_{j t}=\sum_{J \in I} g_{i t} \frac{x_{i t}}{X_{j t}} \quad \forall i: \quad g_{i t}>0,
$$

where $X_{j t}$ represents the size of sector $J$ and $I$ is the set of all establishment in sector $j$ at time $t$. Job destruction rate, $J D_{j t}$, is defined analogously for declining establishments. Gross job reallocation in sector $j$ at time $t, J R_{j t}$, is simply the sum of gross job creation and destruction while the difference between the two, $N E T_{j t}$ is the traditional measure of net employment changes. Since we do not observe jobs, vacancies and entry and exit, the measurement criteria adopted underestimate the true measures of job creation and destruction. For the first two problems there is little one can do about it. The problem with entry and exit is potentially more serious. However, Hamermesh (1993) and OECD (1994) estimate the relative importance of the various flows of jobs and conclude that the contribution to net and gross employment changes of continuing firms accounts for roughly 70 percent of the gross flow of jobs. With this coefficient in mind, we proceed to the calculation of the flows.

\subsection{A Brief Look at the Aggregate Flows}

Figure (1) plots aggregate manufacturing employment over time. The second half of the eighties is a period of sustained net job creation with overall employment growth equal to 7 percent between 1984 and 1990. Table (1) reports the time series introduced in the previous section and Figure (2) plots the series against time. Values for net employment changes indicate that between 1984 and 1990 employment fluctuates substantially, with more than 3 percent employment growth in 1984 and 1988 and almost 2 percent fall in 1985. Correlation values in Table (1) show that employment changes are strongly correlated with both job creation and destruction. Job reallocation, with the exception of 1986 and 1987 is approximately constant, and does not show any increase during the recession, as in U.S. data compiled by Davis and Haltiwanger (1990). 


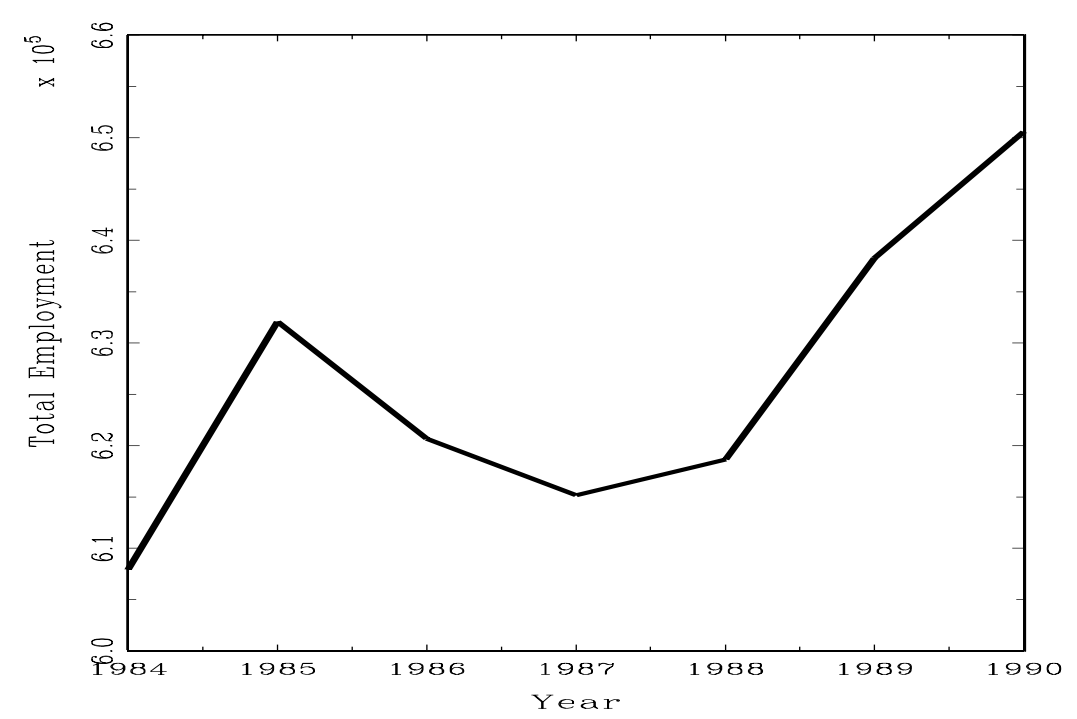

Figure 1: Manufacturing Employment 1984-1990

Table 1: Job Flows in the Mexican Manufacturing Sector

\begin{tabular}{|l|c|c|c|c|}
\hline \hline Year & $\begin{array}{c}\text { Job } \\
\text { Creation } \\
J C\end{array}$ & $\begin{array}{c}\text { Job } \\
\text { Destruction } \\
J D\end{array}$ & $\begin{array}{c}\text { Net Employment } \\
\text { Change } \\
N E T\end{array}$ & $\begin{array}{c}\text { Job } \\
\text { Reallocation } \\
J R\end{array}$ \\
\hline $1984-85$ & 7.49 & 3.6 & 3.89 & 11.09 \\
\hline $1985-86$ & 4.65 & 6.47 & -1.82 & 11.19 \\
\hline $1986-87$ & 4.29 & 5.18 & -0.89 & 9.48 \\
\hline $1987-88$ & 4.66 & 4.1 & 0.56 & 8.77 \\
\hline $1988-89$ & 7.2 & 4.08 & 3.11 & 11.29 \\
\hline $1989-90$ & 6.77 & 4.86 & 1.91 & 11.64 \\
\hline \hline Pearson & $\rho(J C, N E T)$ & $\rho(J D, N E T)$ & & $\rho(J R, N E T)$ \\
Correlat. & 0.932 & -0.859 & & 0.4 \\
& $(0.006)$ & $(0.028)$ & & $(0.421)$ \\
\hline \hline
\end{tabular}

Marginal significance in parenthesis 


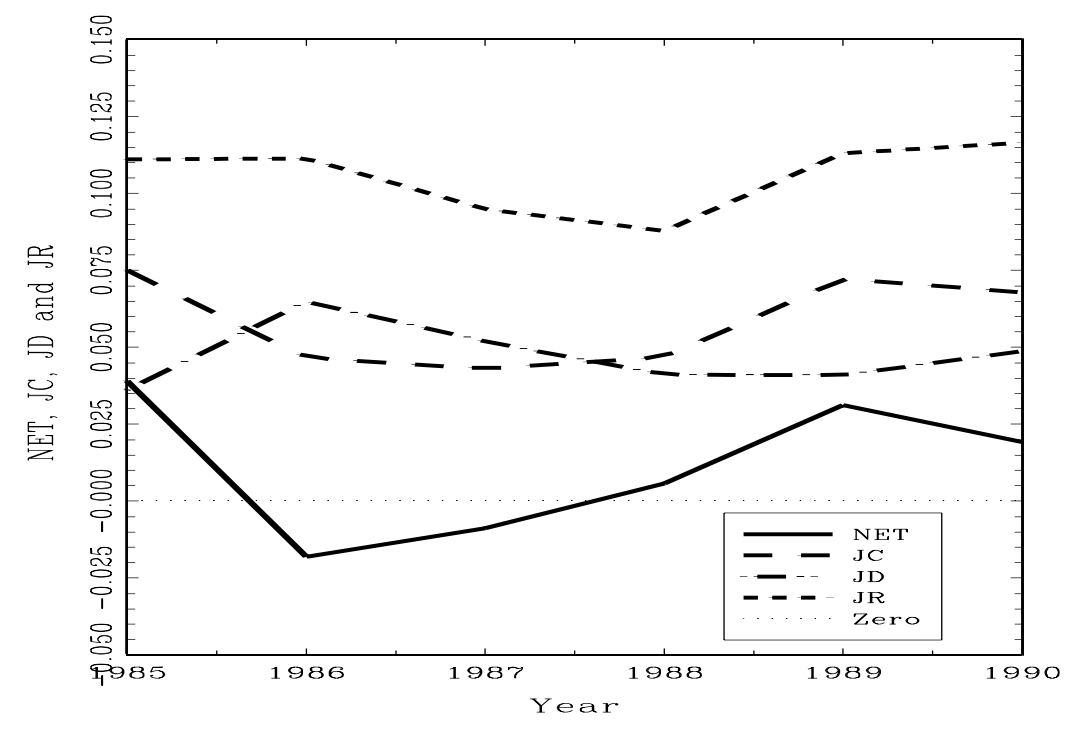

Figure 2: Aggregate Job Flows: 1984-1990 


\section{Job Flows and Firm Size. The Traditional Ap- proach: Assessment and Measures.}

The definition of gross job flows in (2) depends clearly on the way establishment size is defined. Different size definitions yield different results. In this section I show how the results are affected by each definition and I discuss the methodological problems associated with each measure.

When we measure establishment size by employment in the base year, across countries, two statistical regularities hold. Table (2) reports the distribution of gross job flows and employment by establishment size for eight OECD countries. Job reallocation declines sharply as a function of size. R\&P (1995) argues that the "empirical evidence in favour of the inverse relationship between job turnover and firm size appears to be the only sure result that we have... It shows up in all countries, independently of the data sources and methodology, as well as of the prevailing institutions". Table (2) reports also a remarkable relationship between net employment changes and firm size. For 7 out of 8 countries in the sample net job creation is positive in small firms, while the opposite seems true for large firms. In this section we consider in some details these findings and we point out why the second relationship is based on a common regression fallacy and thus totally uninformative on the role of small firms in the job creation process.

Table (3) reports gross flows by establishment size for the Mexican manufacturing sector and confirms the empirical regularities found in the OECD economies of Table (2). Job reallocation is more than 23 percent for the smallest size category and declines sharply as a function of size. Furthermore, with an average employment growth of 1 percent, large firms underperform the aggregate economy while, at the same time, small firms grow at an exceptional average rate of 11 percent. The 11 percent growth is entirely driven by the average creation rate of over 17 percent.

Recently, a number of scholars, notably Davis et al. (1995), have pointed out the statistical problems linked to the results in Table (3). Firstly, higher rates of job creation by small establishments should be treated with particular attention. Given our measure of job flows, it turns out that a firm of size 10 that creates and destroys one job records a reallocation rate of $20 \%$, while if the same two jobs had been created by an establishment of 100 employees, the same figure would be $2 \%$. Furthermore, higher net employment changes by small firms do not imply by themselves that small establishments create proportionally more jobs. Such conclusions should also consider the share of job creation with respect to 
Table 2: Net Employment Change by Establishment Size Class across the OECD

\begin{tabular}{|c|c|c|c|c|}
\hline Country & period & Size & $\begin{array}{c}\text { Job } \\
\text { Reallocation }\end{array}$ & $\begin{array}{c}\text { Net } \\
\text { Changes }\end{array}$ \\
\hline Canada & $\overline{1983-91}$ & $\begin{array}{c}<20 \\
20-99 \\
100-499 \\
>500\end{array}$ & $\begin{array}{l}39.01 \\
26.89 \\
26.15 \\
15.99\end{array}$ & $\begin{array}{c}7.36 \\
2.21 \\
0.92 \\
-0.41\end{array}$ \\
\hline Finland & $1986-91$ & $\begin{array}{c}<20 \\
20-99 \\
100-499 \\
>500\end{array}$ & $\begin{array}{l}29.83 \\
19.85 \\
18.37 \\
16.59\end{array}$ & \begin{tabular}{r|}
2.46 \\
-2.32 \\
-4.27 \\
-6.86 \\
\end{tabular} \\
\hline Germnay & $1986-91$ & $\begin{array}{c}<20 \\
20-49 \\
50-99 \\
100-249 \\
250-499 \\
500-999 \\
1000-2499 \\
2500-4999 \\
>5000\end{array}$ & $\begin{array}{c}32.31 \\
18.20 \\
13.75 \\
12.25 \\
13.98 \\
11.31 \\
16.77 \\
8.8 \\
8.47\end{array}$ & $\begin{array}{c}0.57 \\
-2.20 \\
-3.49 \\
-3.89 \\
-4.96 \\
-4.83 \\
-14.19 \\
-7.32 \\
-8.47\end{array}$ \\
\hline Italy & 1984-93 & $\begin{array}{c}<5 \\
6-9 \\
10-19 \\
20-49 \\
50-99 \\
100-199 \\
200-499 \\
500-999 \\
>1000\end{array}$ & $\begin{array}{c}43.49 \\
30.78 \\
25.41 \\
20.77 \\
17.38 \\
15.15 \\
13.47 \\
12.34 \\
8.76\end{array}$ & $\begin{array}{c}6.36 \\
0.08 \\
-0.84 \\
-1.32 \\
-1.30 \\
-1.52 \\
-1.42 \\
-1.43 \\
-2.28\end{array}$ \\
\hline New Zeland & $\overline{1987-92}$ & $\begin{array}{c}<20 \\
20-99 \\
100-499 \\
>500\end{array}$ & $\begin{array}{l}37.67 \\
32.77 \\
21.57 \\
45.07\end{array}$ & $\begin{array}{c}0.96 \\
-6.13 \\
-3.55 \\
-20.56\end{array}$ \\
\hline Sweden & 1985-92 & $\begin{array}{c}<20 \\
20-99 \\
100-499 \\
>500\end{array}$ & $\begin{array}{l}39.84 \\
25.31 \\
21.57 \\
21.82\end{array}$ & $\begin{array}{c}5.64 \\
-1.86 \\
-3.55 \\
-5.48\end{array}$ \\
\hline U.K. & $1987-89$ & $\begin{array}{c}<5 \\
5-9 \\
10-19 \\
20-49 \\
50-99 \\
100-499 \\
500-999 \\
1000-4999 \\
5000-9999 \\
>10000\end{array}$ & $\begin{array}{c}77.50 \\
48.6 \\
34.40 \\
26.90 \\
24.00 \\
23.4 \\
26.40 \\
16.10 \\
20.8 \\
7.3\end{array}$ & $\begin{array}{c}34.1 \\
11.2 \\
5.20 \\
4.10 \\
5.80 \\
4.2 \\
8.60 \\
1.10 \\
1.60 \\
2.1 \\
\end{array}$ \\
\hline U.S. & $1973-88$ & $\begin{array}{c}19 \\
20-49 \\
50-99 \\
100-249 \\
250-499 \\
500-999 \\
1000-2499 \\
2500-4999 \\
5000-9999\end{array}$ & $\begin{array}{l}41.1 \\
26.7 \\
23.4 \\
20.6 \\
17.3 \\
15.3 \\
14.1 \\
13.3 \\
11.8\end{array}$ & $\begin{array}{c}10.3 \\
0.6 \\
-0.7 \\
-1.7 \\
-2.5 \\
-2.7 \\
-2.6 \\
-2.5 \\
-2.4\end{array}$ \\
\hline
\end{tabular}

Source: R\&P (1995) and reference therein;

U.S. figure from Davis et al. (1995) 
Table 3: Job Flows by Establishment Size Category

Establishment Size as Employment in Base Year

\begin{tabular}{|l|c|c|c|c|c|}
\hline \hline & $\begin{array}{c}\text { Employees } \\
<20\end{array}$ & $\begin{array}{c}\text { Employees } \\
20-50\end{array}$ & $\begin{array}{c}\text { Employees } \\
51-99\end{array}$ & $\begin{array}{c}\text { Employees } \\
100-500\end{array}$ & $\begin{array}{c}\text { Employees } \\
>500\end{array}$ \\
\hline $\begin{array}{l}\text { Average Job } \\
\text { Creation }\end{array}$ & 17.33 & 9.07 & 8.42 & 6.66 & 5.1 \\
\hline $\begin{array}{l}\text { Average Job } \\
\text { Destruction }\end{array}$ & 5.99 & 4.9 & 5.2 & 4.7 & 4.71 \\
\hline $\begin{array}{l}\text { Average Job } \\
\text { Reallocation }\end{array}$ & 23.33 & 14.01 & 13.68 & 11.3 & 9.8 \\
\hline $\begin{array}{l}\text { Average Net } \\
\text { Change }\end{array}$ & 11.3 & 4.08 & 3.1 & 1.9 & 0.39 \\
\hline \hline
\end{tabular}

Average weighted by the number of jobs in each year

the employment share by each category. Table (4) takes explicitly into consideration the shares and the proportion of jobs created by each category. The fraction of jobs created by each category over the employment share in the same category is a measure independent of the relative size of the category and, consequently, a proper comparison across categories can be made. On average the ratio between the share of jobs created by small firms over their employment share is more than 3 , against 0.86 for the establishments with more than 500 employees. Among the two extremes, the relationship falls monotonically. It is necessary to stress the difference between net and gross flows before reaching any conclusion from this partial result. In Table (4) I calculate the same ratio for job destruction and it turns out that small firms also play a more active role in the process of job destruction. Again, the relationship between our proportional measure of job destruction and firm size falls monotonically. Even though small firms more than proportionally create and destroy jobs, the last rows of Table (4) shows that the difference between rows 2 and 3 in Table (4) is positive for small firms and negative only for the very large firms. Overall, Table (4) confirms a more active role of small establishments in the process of net job formation.

Naturally, from the results of Table (4), we expect the growth rate of each firm to be negatively correlated to its initial size. Establishment growth rate regressions and studies on the evolution of the size distribution have been at the core of a large literature in Industrial Organisation (Evans 1987a; 1987b). The simplest version of a firm growth model is one in 
Table 4: Proportional Measure of Job Flows by Establishment Size Category

\begin{tabular}{|l|c|c|c|c|c|}
\hline \hline & $\begin{array}{c}\text { Employees } \\
<20\end{array}$ & $\begin{array}{c}\text { Employees } \\
20-50\end{array}$ & $\begin{array}{c}\text { Employees } \\
51-99\end{array}$ & $\begin{array}{c}\text { Employees } \\
100-500\end{array}$ & $\begin{array}{c}\text { Employees } \\
>500\end{array}$ \\
\hline $\begin{array}{l}\text { Average Employment } \\
\text { Share }\end{array}$ & 0.2 & 1.6 & 4.5 & 36.4 & 58.1 \\
\hline $\begin{array}{l}\text { Share of Job Creation } \\
\text { (a) }\end{array}$ & 3.15 & 1.56 & 1.45 & 1.13 & 0.86 \\
\hline $\begin{array}{l}\text { Share Job Destruction } \\
\text { (bmployment Share }\end{array}$ & 1.27 & 1.06 & 1.11 & 1.00 & 0.98 \\
\hline $\begin{array}{l}\text { Net Proportional } \\
\text { Share }\end{array}$ & 1.87 & 0.50 & 0.34 & 0.13 & -0.12 \\
\hline \hline
\end{tabular}

(a) Job created by each category over employment share in the same category

(b) Job destroyed by each category over employment share in the same category 
Table 5: Regressions of Establishment Growth Rate on Establishment Size

Establishment Size as Employment in Base Year

Dependent Variable: Growth Rate of Establishment $\mathrm{i}$ at time $\mathrm{t}$

\begin{tabular}{|l|c|c|c|}
\hline \hline \multirow{2}{*}{$\ln (\text { employment })_{\text {it }}$} & $(1)$ & $(2)$ & $(3)$ \\
& $(-0.0097$ & -0.0096 & -0.0141 \\
& $(-6.28)$ & Yes & Yes \\
\hline Time Dummies & No & No & Yes \\
\hline Industry Dummies & No & 12126 & 12126 \\
\hline$F$ statistic & $F(1,12124)=39.461$ & $F(1,12118)=22.059$ & $F(1,12124)=4.999$ \\
\hline Number of & 12126 & & \\
Observations & & & \\
\hline \hline
\end{tabular}

t statistics in parentheses

which growth rates are independent of initial size, as predicted by the well-known Gibrat's Law. We thus estimate

$$
\frac{\ln \left(x_{i, t}\right)-\ln \left(x_{i, t-1}\right)}{\Delta t}=a+b \ln \left(x_{i, t-1}\right)+u_{i t},
$$

where $x_{i t}$ and $x_{i t-1}$ are employment in establishment $i$ at time $t$ and $t-1, \Delta t$ is the time interval between successive observations and $u_{i t}$ is a white noise. Regressions in Table (5) estimate a negative and significant coefficient on initial size, even when we control for sectoral and time characteristics. Regressions in Table (5) are only illustrations of well-known results in the Industrial Organization literature and equations in the spirit of (3) have been considered as evidence against Gibrat's law. Results in Tables (3),(4) and (5) all point towards the same conclusion and should throw evidence on an important relationship between job creation and small firms.

Despite the evidence provided in Tables (3), (4) and (5) several difficulties remain. The major problem connected with the role of small firms in the job creation process is the statistical fallacy known as the Galton fallacy, or regression to the mean. The regression bias arises in any longitudinal data set and has received particular attention in the empirics of economic growth (Quah (1993a) and Friedman (1992). Technically, because of the Galton fallacy, when we regress net employment changes by firms on initial employment, a negative coefficient on initial size, exactly as in Table (5), is uninformative about the relationship between initial size and firm growth ${ }^{1}$. Intuitively, results in Tables (3), (4) and (5) can be

\footnotetext{
${ }^{1}$ Quah (1993b) shows why a negative coefficient in regressions in Table (6) is consistent with a stationary standard deviation in the underlying distribution.
} 
affected by the regression fallacy for the following reason. If a firm suffers from transitory deviation of employment around its long-term optimum size, temporarily smaller firms will gain jobs during their path to equilibrium, and vice-versa for temporarily larger firms. If establishment size is measured as employment in base year, the existence of temporary deviation would bias upward job creation by small firms and job destruction by large firms. Consequently, when we regress firm growth over initial employment, a negative coefficient on initial size may simply capture the existence of temporary shocks, without telling anything about the underlying relationship between firm size and firm growth.

Davis et al. (1995) propose a measure of establishment size that tries to capture an establishment optimal long- run size. To avoid the regression fallacy, they attribute job flows to a smaller or larger size category calculating the average size across all observations in the sample. In their study for the U.S. manufacturing sector, they do not find any systematic relationship between establishment size and long-run firm size measure.

Table (6) computes job flows by firm size measuring establishment size as the average employment over all years in the sample. Table (6) is constructed using the same size category as Table (4), but assigning an establishment to each category according to its average employment between 1984 and 1990. The first row of Table 6 reverses the results of Table (3) and shows a positive monotonic relationship between establishment size and net employment changes. Similar conclusions hold for the bottom row of Table (6), which replicates the calculation of Table (4) with the new long-run size. A casual interpretation of the result of Table (6) indicates that small firms more than proportionally destroy jobs.

Even though Table (6) may partially avoid the regression fallacy, it does not give us a clear answer on the relationship between firm size and job flows. Results in Table (6) may simply indicate that firms initially small ( large) created (destroyed) jobs throughout the period and ended up relatively large (small). Furthermore, to the extent that the latter interpretation is correct, it seems that substantial dynamics between category is taking place. In all the Tables so far presented, we focused exclusively on within category job creation and this practice, by construction, hides any intradistribution dynamics. This discussion should highlight the fact that the definition of small and large establishments is a relative concept and any such definition is somehow arbitrary. In the next section I consider an alternative econometric technique that allows us to measure job flows and firm size avoiding the Galton fallacy and explicitly considering job flows between size categories. 
Table 6: Proportional Measure of Job Flows by Establishment Size Category

Firm Size as Average Employment between 1984 and 1990

\begin{tabular}{|l|c|c|c|c|c|}
\hline \hline & $\begin{array}{c}\text { Employees } \\
<20\end{array}$ & $\begin{array}{c}\text { Employees } \\
20-50\end{array}$ & $\begin{array}{c}\text { Employees } \\
51-99\end{array}$ & $\begin{array}{c}\text { Employees } \\
100-500\end{array}$ & $\begin{array}{c}\text { Employees } \\
>500\end{array}$ \\
\hline $\begin{array}{l}\text { Average Employment } \\
\text { Share }\end{array}$ & 0.2 & 1.6 & 4.5 & 31.4 & 63.0 \\
\hline $\begin{array}{l}\text { Average Job } \\
\text { Creation }\end{array}$ & 7.62 & 6.41 & 6.72 & 6.37 & 5.43 \\
\hline $\begin{array}{l}\text { Average Job } \\
\text { Destruction }\end{array}$ & 8.52 & 6.79 & 6.3 & 5.2 & 4.18 \\
\hline $\begin{array}{l}\text { Average Job } \\
\text { Reallocation }\end{array}$ & 16.1 & 13.2 & 13.07 & 11.6 & 9.6 \\
\hline $\begin{array}{l}\text { Average Net } \\
\text { Change }\end{array}$ & -0.009 & -0.003 & 0.003 & 1.11 & 1.25 \\
\hline $\begin{array}{l}\text { Share of Job Creation } \\
\text { (a) }\end{array}$ & 1.26 & 1.10 & 1.14 & 1.09 & 0.91 \\
\hline $\begin{array}{l}\text { Employment Share } \\
\text { Share Job Destruction } \\
\text { (b) }\end{array}$ & 1.73 & 1.44 & 1.34 & 1.10 & 0.87 \\
\hline $\begin{array}{l}\text { Employment Share Proportional } \\
\text { Share }\end{array}$ & -0.47 & -0.34 & -0.19 & -0.01 & 0.037 \\
\hline \hline
\end{tabular}

(a) Job created by each category over employment share in the same category

(b) Job destroyed by each category over employment share in the same category 

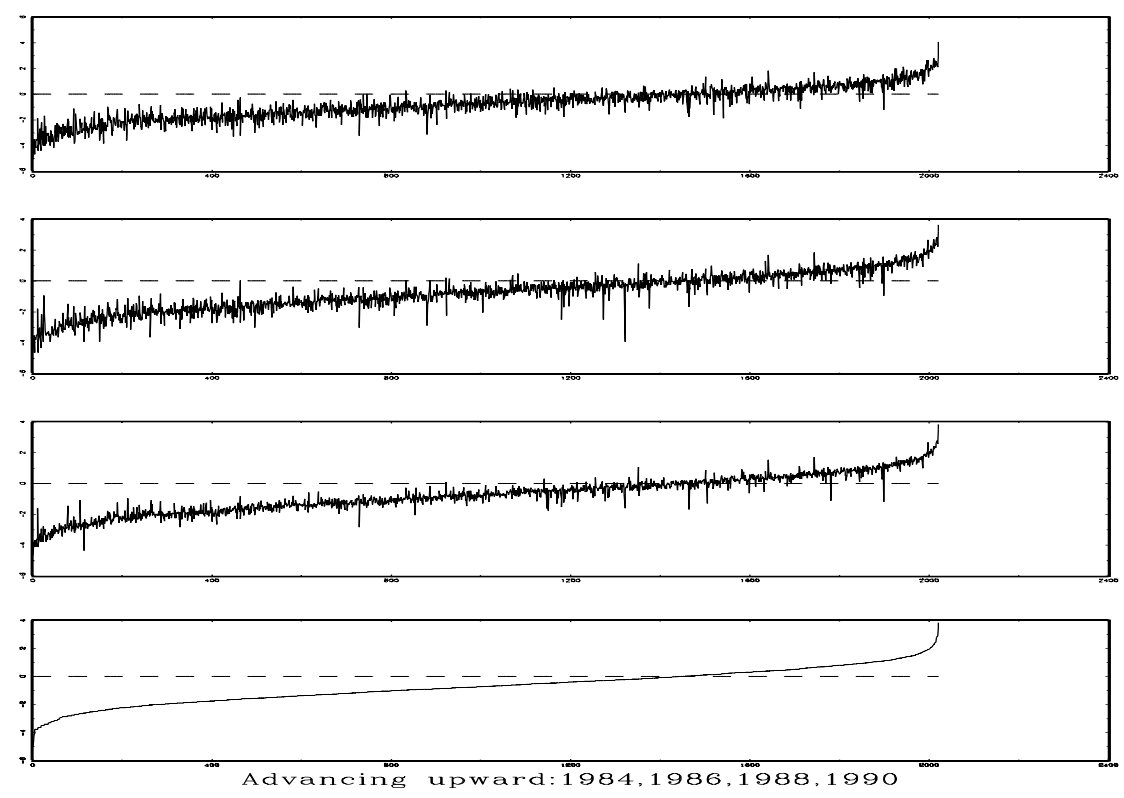

Figure 3: Ranking of Establishments Over Time

\section{Job Flows Between Category and Analysis of Con- vergence}

The analysis of the previous section suggested that substantial intradistribution dynamics may take place and a considerable number of firms are overtaking each other. A first way of looking at the problem in a different way is as follows. Let $n_{i t}$ denote employment in establishment $i$ at time $t$, and let us analyse the natural $\log$ of relative size $\left(n_{i t} / \bar{n}_{t}\right)$, where $\bar{n}_{t}$ is the average employment in the sample at time t. Figure (3) plots the size distributions in the following way. Arrayed along the horizontal axis are more than 2000 establishments in the sample, sorted in order of increasing 1984 relative size $n_{i t} / \bar{n}_{t}$. The horizontal line at height 0 indicates the average establishment at time $t$.

In Figure (3), monotonic by construction, any establishment below (above) the dotted line in the first panel has employment lower (higher) than the average in 1984. Proceeding 
further vertically upwards in Figure (3), we plot additional cross-profile lines at two year intervals (1986,1988 and 1990). In these graphs, firms overtake each other when succeeding cross-profiles become non-monotone. As suggested by Quah (1994), to understand better these graphs, let us consider two simple experiments. Suppose the cross-section of establishments were only adjusting towards the same steady state without overtaking each other, i.e. converging towards the mean. Then the profile in Figure (3) should maintain its monotonic property and its slope flatten out. This is not what unambiguously happens in Figure (3). Suppose, conversely, that establishments of different size were steadily diverging from each other. This time the cross-profile should still maintain its monotonic property, but with an increasing slope over time. As before, this is not what we see in the graph. The only obvious conclusion from Figure (3) is that firms continuously overtake each other and the monotonicity property of the first chart is lost over time. In this context, what we really need are econometric methods that allow us to measure job creation between size categories. Methodology for this purpose has been recently introduced by Quah (1993a; 1994) in the empirics of economic growth.

In what follows, let $F_{t}$ denote the size distribution across establishments at year $t$; Quah suggests that the simplest probability model that can describe the dynamic behaviour of $F_{t}$ is

$$
F_{t}=T^{*}\left(F_{t-1}, u_{t}\right)
$$

where $T^{*}$ is an operator that maps a probability measure and a disturbance into another probability measure. Note that carrying out aggregate statistics of $F$, as we did in the previous section, would not suffice since we would hide any intra distribution dynamics. Furthermore, if we are interested in the long-run behaviour of the size distribution we can proceed as follows. If we ignore the disturbance term $u_{t}$ and we iterate expression (4), the size distribution at time $s>t$ can be described as

$$
F_{t+s}=\left(T^{*}\right)^{s} F_{t}
$$

Finally, if we let $s$ go to infinity, the long-run (ergodic) distribution of establishment size can be characterised. In this context convergence (towards the mean) might manifest in $F_{t+s}$ tending towards a mass point; alternatively the size distribution partitioning in small and large firms might be described by $F_{t+s}$ being characterized by two points or a bimodal distribution.

Note that the stochastic difference equation (5) is untractable. The problem with (5) is that as long as $F$ is a continuous variable, there are an infinite number of states. In this 
paper we focus on the simplest treatment we can have of (5) and we simplify the problem by approximating $T^{*}$ in the following way. We first assume a countable state space for firm size $S=s 1, \ldots, s r$ and we transform $T^{*}$ into a simple transition probability matrix $Q$, which makes the difference equation (5) tractable. The problem becomes simply

$$
F_{t+1}=Q F_{t}
$$

where $Q$ encodes all the relevant information about mobility within the cross section distribution and allows us to study the long-run ergodic size distribution of firms. The framework set forth let us infer both intradistribution dynamics encoded in the matrix $Q$ and its long-run ergodic behaviour through successive iteration.

\section{Results}

To avoid the problems of arbitrariness in the size definition, we consider employment size with respect to the average establishment in each year. Category thresholds are determined to make the initial distribution of firms uniform. Since we choose five categories, the initial proportion of establishments in each category is 0.2 . Table (7) shows the estimate of a one year transition matrix for the total manufacturing sector. In Table (7) the upper end of the state 0.175 indicates that in the first category we find all establishments whose employment is less of 17.5 percent than the average establishment in 1984. The mean establishment falls in the fourth category. Given these categories, we estimate the transition probability for each year of observation. We obtain six estimates and, averaging out across time, we obtain the Markov chain of Table (7). Obviously most of the probability lies in the main diagonal. This is a simple indication that employment is highly persistent. Furthermore, entries in the main diagonal are higher in the first and last rows. This follows simply from the fact that firms in those categories can only move in one direction. One of the most important observations from Table (7) concerns elements in the third row. The establishments in the third category have a higher probability of becoming smaller than bigger, the contrary to what we would expect in a world where establishments converge towards the mean. Similarly, the probability mass of an establishment moving from the first to the second row is smaller than the probability of falling from the second to the first row. Finally, plants in the fourth category have an higher probability of falling into the third category than moving up. The last row in Table (7) reports the ergodic distribution implied by entries in Table (7) and it does not show any evidence of establishment size converging to the mean. If anything, 
Table 7: One Year Transition Matrix

Average 1984-1990. Total Manufacturing

Time Stationarity

\begin{tabular}{|l|c|c|c|c|c|}
\hline \hline $\begin{array}{l}\text { Upper end of } \\
\text { the state }\end{array}$ & 0.175 & 0.355 & 0.665 & 1.37 & $\infty$ \\
\hline 0.175 & 0.925 & 0.0714 & 0.00322 & 0.00 & 0.00 \\
\hline 0.355 & 0.0847 & 0.823 & 0.0890 & 0.0037 & 0.00 \\
\hline 0.665 & 0.0042 & 0.0883 & 0.824 & 0.0823 & 0.0085 \\
\hline 1.37 & 0.00123 & 0.0045 & 0.0826 & 0.0849 & 0.0629 \\
\hline$\infty$ & 0.00 & 0.0008 & 0.000161 & 0.0668 & 0.931 \\
\hline \hline Ergodic & 0.242 & 0.20 & 0.196 & 0.188 & 0.174 \\
\hline \hline
\end{tabular}

there is some evidence of an increasing weight of the smaller category, but no evidence of convergence to the mean by initially small and large establishments, as results in Tables (3),(4) and (5) would predict. Table (8) confirms the results of Table (7), for a one step transition matrix. What is happening to intradistribution dynamics is a large movement of initially larger establishments toward a smaller size category, with no evidence of a persistent growth by initially smaller firms towards the mean.

Firm size evolution depends primarily upon technological characteristics and market structure typical of the industry in which each establishment operates. After all, once we have realized that there is nothing peculiar in the behaviour of small firms as a whole, we can start looking at what happens within each industry. In what follows we ask the following questions. Is regression to the mean observed in any industrial sector, independently of its employment dynamics? Alternatively, do we observe different size distribution dynamics in different sectors? If convergence is not observed in some sectors, is this phenomenon correlated with some other observable characteristics, such as average firm size, changes in the average firm size? Is there any relationship between job flow magnitude and long-run behaviour of the sector?

The appendix reports the upper limit of the categories for 10 sectors for which I estimate the transition probability. Even though there are some differences in the initial size distribution, each sector has the mean in its fourth category. The appendix shows also the transition probability matrix for each sector and the ergodic distribution. The transition 
Table 8: 5 Years Transition Matrix

Average 1984-1990. Total Manufacturing

\begin{tabular}{|l|c|c|c|c|c|}
\multicolumn{7}{c|}{ Time Stationarity } \\
\hline \hline $\begin{array}{l}\text { Upper end of } \\
\text { the state }\end{array}$ & 0.175 & 0.355 & 0.665 & 1.37 & $\infty$ \\
\hline 0.175 & 0.832 & 0.151 & 0.173 & 0.00 & 0.00 \\
\hline 0.355 & 0.218 & 0.576 & 0.19 & 0.015 & 0.00 \\
\hline 0.665 & 0.0198 & 0.183 & 0.587 & 0.20 & 0.0099 \\
\hline 1.37 & 0.0495 & 0.00173 & 0.218 & 0.636 & 0.124 \\
\hline$\infty$ & 0.00 & 0.0483 & 0.0217 & 0.145 & 0.829 \\
\hline \hline Ergodic & 0.287 & 0.198 & 0.203 & 0.175 & 0.13 \\
\hline \hline
\end{tabular}

probability matrix shows that, as expected, the highest probability lies in the main diagonal, but entries in the other cells are non-zero. As expected, firm employment is highly persistent, but intradistribution dynamics exist.

Table (9) looks in more details at the ergodic distribution in each sector and a series of other statistics related to job flows. The first result in Table (9) is the difference in the ergodic behaviour across industries. Wood and Chemical industry shows some evidence of convergence, with the highest probability clearly in the fourth category. The same ergodic behaviour is not observed in other industries. Non-Metallic sector registers a different form of convergence, with a bimodal concentration of firms in the second and the fourth category. Textile and Clothing, the Car industry and paper are characterized by a totally different ergodic behaviour, with the mode concentrated in the highest category. Finally food, metal, machinery and equipment and beverages, show no clear pattern of mobility. Table (9) also reports, for each sector, average net employment change, job reallocation, average establishment size, the proportional change in the mean over time and a measure of Shorrocks (in Geweke et al. (1986)) mobility index of persistence, defined as

$$
M(P)=\frac{n-\operatorname{tr}(P)}{n-1},
$$

where $M$ is the mobility index, $P$ is the Markov chain, $n$ is the number of categories and $\operatorname{tr}(P)$ is the trace of $P$. A value of $M(P)$ of 0 indicates an absolute persistence in the process, whereas a value of $n / n-1$ indicates the highest possible mobility. 
Table 9: Mobility and Convergence Across Sectors

Average 1984-1990. Total Manufacturing

Time Stationarity

\begin{tabular}{|c|c|c|c|c|c|c|}
\hline Industry & $\begin{array}{l}\text { Ergodic Distribution } \\
5 \text { Size categories }\left(^{*}\right)\end{array}$ & $\begin{array}{c}N E T \\
\text { (a) }\end{array}$ & $\begin{array}{l}J R \\
\text { (b) }\end{array}$ & $\begin{array}{l}\text { Average } \\
\text { Mean (c) }\end{array}$ & $\begin{array}{c}\text { Mean } \\
\text { Change (d) }\end{array}$ & $\begin{array}{l}\text { Mobility } \\
\text { Index (e) }\end{array}$ \\
\hline \multicolumn{7}{|l|}{ Group 1: } \\
\hline Wood & $\begin{array}{llllll} & 0.17 & 0.14 & 0.22 & 0.24 & 0.21\end{array}$ & 0.1 & 7.5 & 181.6 & 0.01 & 0.158 \\
\hline Chemical & $\begin{array}{llllll}0.18 & 0.15 & 0.20 & 0.24 & 0.21\end{array}$ & 1 & 7.9 & 263 & 0.07 & 0.151 \\
\hline \multicolumn{7}{|l|}{ Group 2: } \\
\hline Textile & $\begin{array}{llllll}0.17 & 0.12 & 0.12 & 0.22 & 0.34\end{array}$ & -1 & 7.9 & 295.1 & -0.06 & 0.175 \\
\hline Car & $\begin{array}{llllll}0.06 & 0.12 & 0.20 & 0.31 & 0.30\end{array}$ & -1.5 & 10.7 & 266.5 & -0.1 & 0.155 \\
\hline Paper & $\begin{array}{llllll}0.09 & 0.11 & 0.09 & 0.18 & 0.51\end{array}$ & -0.6 & 8.3 & 161.9 & -0.037 & 0.184 \\
\hline \multicolumn{7}{|l|}{ Group 3: } \\
\hline Beverages & $\begin{array}{llllll}0.17 & 0.21 & 0.17 & 0.20 & 0.22\end{array}$ & 1.9 & 8.2 & 765.1 & 0.15 & 0.187 \\
\hline Machinery & $\begin{array}{lllll}0.38 & 0.12 & 0.21 & 0.18 & 0.09\end{array}$ & 2.7 & 10.0 & 667.6 & 0.209 & 0.176 \\
\hline Metal & $\begin{array}{llllll}0.18 & 0.19 & 0.23 & 0.19 & 0.19\end{array}$ & 0.8 & 11 & 284 & 0.06 & 0.227 \\
\hline Food & $\begin{array}{llllll}0.28 & 0.23 & 0.18 & 0.16 & 0.12\end{array}$ & 1.6 & 9.2 & 238 & 0.12 & 0.162 \\
\hline \multicolumn{7}{|l|}{ Group 4: } \\
\hline Non Metalic & $\begin{array}{llllll}0.16 & 0.25 & 0.19 & 0.23 & 0.15\end{array}$ & 0.0 & 9.0 & 323 & 0.003 & 0.162 \\
\hline
\end{tabular}

(*) For upper limit of the initial distribution see Appendix

(a) Net employment change between 1984 and 1990

(b) Job Reallocation

(c) Average Establishment Size

(d) Proportional Change in the Mean

(e) Shorrock Mobility Index 
Table (9) shows that for the converging sectors average net employment change is approximately constant and the proportional change in the mean is slightly positive. If we take a simple average between groups of sectors, job reallocation for Wood and Chemical sectors and the Shorrocks index are the smallest between all groups. Conversely, the second group (textile, car and paper) has a downward shifting of the mean and a negative average net employment change. Both job reallocation and the mobility indices are, on average, higher than the corresponding values for the converging sectors. On the other hand, group 3 is characterized by a substantial increase in the mean, roughly 15 percent. Note that the mobility index for group 3, on average .19, is the highest among the three groups of sectors identified. Similarly for job reallocation, with an average value of .096.

Table (9) suggests that firm size distribution dynamics in each sector is linked to the dynamic behaviour of the sector as a whole. Relatively stable sectors, with small changes in both the mean and total employment (group 1) converge to the mean with relatively little intradistribution dynamics. On the other hand, declining sectors, such as those in group 2, experience a mass concentration into the highest size categories. Finally, expanding sectors (group 3) do not show any particular tendency in the size distribution, but, as a group, they are characterised by the highest mobility level, both in term of job reallocation and the Shorrock index. These results suggest a remarkable asymmetric behaviour in the size distribution between expanding and declining sectors, and some evidence of convergence for relatively stable sectors.

\section{Conclusions}

In the last decade, much emphasis in the policy debate has been given to the role of small firms in the process of job creation. From an empirical standpoint, when we measure firm size as employment in a base year, it is true that small firms more than proportionally create jobs. In this paper I discussed the problem of how to define establishment size and I measured the relation between job flows and establishment size with different plant size

definitions. I argued that the traditional measures suffer from the Galton fallacy and they are uninformative on the relationship between job flows and establishment size. Applying non parametric techniques best suited for analysing the dynamics of a large cross-section, I did not find any long-run movement of initially small establishments toward the mean, thus no evidence of convergence. Furthermore, applying the analysis at the industry level, I find an interesting asymmetric behaviour in the dynamics of the expanding and declining sector. 
Konings (1995) in a paper that studies the evolution of plant size in the British manufacturing industry finds similar results. The next step would be to apply the same methodology to other datasets and controll to what extent the results of this paper represent a more general result. If these empirical results should be further confirmed, important implications for industry dynamics would naturally follow.

\section{Appendix: Transition Matrices at the Industry Level}

In this section I report the one year transition matrices for the 10 industries of the Mexican manufacturing sector.

Table 10: Food Industry. First Order Transition Matrix

Average 1984-1990. Food Industry

Time Stationarity

\begin{tabular}{|l|c|c|c|c|c|}
\hline \hline $\begin{array}{l}\text { Upper end of } \\
\text { the state }\end{array}$ & 0.225 & 0.390 & 0.670 & 1.38 & $\infty$ \\
\hline 0.225 & 0.939 & 0.052 & 0.008 & 0.00 & 0.00 \\
\hline 0.390 & 0.068 & 0.842 & 0.047 & 0.005 & 0.00 \\
\hline 0.670 & 0.005 & 0.115 & 0.809 & 0.07 & 0.00 \\
\hline 1.38 & 0.00 & 0.0103 & 0.074 & 0.862 & 0.0538 \\
\hline$\infty$ & 0.00 & 0.000 & 0.000 & 0.070 & 0.929 \\
\hline \hline Ergodic & 0.287 & 0.238 & 0.183 & 0.166 & 0.126 \\
\hline \hline
\end{tabular}

Table 11: Beverages Industry. First Order Transition Matrix

Average 1984-1990. Beverages Industry

Time Stationarity

\begin{tabular}{|l|c|c|c|c|c|}
\hline \hline $\begin{array}{l}\text { Upper end of } \\
\text { the state }\end{array}$ & 0.310 & 0.645 & 0.950 & 1.32 & $\infty$ \\
\hline 0.310 & 0.929 & 0.066 & 0.011 & 0.00 & 0.00 \\
\hline 0.645 & 0.062 & 0.823 & 0.115 & 0.00 & 0.00 \\
\hline 0.950 & 0.005 & 0.128 & 0.763 & 0.11 & 0.00 \\
\hline 1.32 & 0.00 & 0.0202 & 0.075 & 0.82 & 0.084 \\
\hline$\infty$ & 0.00 & 0.000 & 0.000 & 0.0768 & 0.923 \\
\hline \hline Ergodic & 0.174 & 0.217 & 0.178 & 0.205 & 0.226 \\
\hline \hline
\end{tabular}


Table 12: Textile and Clothing. First Order Transition Matrix Average 1984-1990. Textile and Clothing Time Stationarity

\begin{tabular}{|l|c|c|c|c|c|}
\hline \hline $\begin{array}{l}\text { Upper end of } \\
\text { the state }\end{array}$ & 0.175 & 0.355 & 0.640 & 1.32 & $\infty$ \\
\hline 0.175 & 0.931 & 0.066 & 0.002 & 0.00 & 0.00 \\
\hline 0.355 & 0.082 & 0.832 & 0.081 & 0.003 & 0.00 \\
\hline 0.640 & 0.00 & 0.072 & 0.826 & 0.098 & 0.002 \\
\hline 1.32 & 0.0058 & 0.027 & 0.058 & 0.861 & 0.0793 \\
\hline$\infty$ & 0.00 & 0.000 & 0.000 & 0.0528 & 0.947 \\
\hline \hline Ergodic & 0.172 & 0.127 & 0.128 & 0.226 & 0.347 \\
\hline \hline
\end{tabular}

Table 13: Wood Industry. First Order Transition Matrix Average 1984-1990. Wood Industry Time Stationarity

\begin{tabular}{|l|c|c|c|c|c|}
\hline \hline $\begin{array}{l}\text { Upper end of } \\
\text { the state }\end{array}$ & 0.27 & 0.490 & 0.815 & 1.41 & $\infty$ \\
\hline 0.27 & 0.923 & 0.0772 & 0.00 & 0.00 & 0.00 \\
\hline 0.49 & 0.0917 & 0.795 & 0.108 & 0.00 & 0.00 \\
\hline 0.815 & 0.00 & 0.0664 & 0.846 & 0.0873 & 0.00 \\
\hline 1.41 & 0.00 & 0.00 & 0.075 & 0.87 & 0.054 \\
\hline$\infty$ & 0.00 & 0.005 & 0.005 & 0.056 & 0.932 \\
\hline \hline Ergodic & 0.172 & 0.145 & 0.229 & 0.245 & 0.21 \\
\hline \hline
\end{tabular}

Table 14: Paper Industry. First Order Transition Matrix

Average 1984-1990. Paper Industry

Time Stationarity

\begin{tabular}{|l|c|c|c|c|c|}
\hline \hline $\begin{array}{l}\text { Upper end of } \\
\text { the state }\end{array}$ & 0.285 & 0.490 & 0.705 & 1.26 & $\infty$ \\
\hline 0.285 & 0.884 & 0.0996 & 0.00 & 0.0167 & 0.00 \\
\hline 0.49 & 0.094 & 0.80 & 0.106 & 0.00 & 0.00 \\
\hline 0.705 & 0.00 & 0.111 & 0.751 & 0.137 & 0.002 \\
\hline 1.26 & 0.00 & 0.0139 & 0.0662 & 0.853 & 0.067 \\
\hline$\infty$ & 0.00 & 0.00 & 0.00 & 0.0238 & 0.976 \\
\hline \hline Ergodic & 0.09 & 0.11 & 0.096 & 0.183 & 0.519 \\
\hline \hline
\end{tabular}


Table 15: Chemical Industry. First Order Transition Matrix Average 1984-1990. Chemical Industry

Time Stationarity

\begin{tabular}{|l|c|c|c|c|c|}
\hline \hline $\begin{array}{l}\text { Upper end of } \\
\text { the state }\end{array}$ & 0.21 & 0.4 & 0.745 & 1.5 & $\infty$ \\
\hline 0.21 & 0.925 & 0.0068 & 0.005 & 0.00 & 0.00 \\
\hline 0.4 & 0.079 & 0.817 & 0.096 & 0.0063 & 0.00 \\
\hline 0.745 & 0.059 & 0.073 & 0.842 & 0.0785 & 0.00 \\
\hline 1.50 & 0.0017 & 0.00 & 0.0678 & 0.874 & 0.056 \\
\hline$\infty$ & 0.00 & 0.00 & 0.00 & 0.063 & 0.937 \\
\hline \hline Ergodic & 0.184 & 0.151 & 0.204 & 0.244 & 0.217 \\
\hline \hline
\end{tabular}

Table 16: Non-metallic Industry. First Order Transition Matrix Average 1984-1990. Chemical Industry

Time Stationarity

\begin{tabular}{|l|c|c|c|c|c|}
\hline \hline $\begin{array}{l}\text { Upper end of } \\
\text { the state }\end{array}$ & 0.11 & 0.28 & 0.620 & 1.59 & $\infty$ \\
\hline 0.11 & 0.923 & 0.072 & 0.0045 & 0.00 & 0.00 \\
\hline 0.28 & 0.0479 & 0.836 & 0.112 & 0.0037 & 0.00 \\
\hline 0.62 & 0.00 & 0.148 & 0.773 & 0.0792 & 0.00 \\
\hline 1.59 & 0.00 & 0.003 & 0.0676 & 0.885 & 0.0436 \\
\hline$\infty$ & 0.00 & 0.00 & 0.00 & 0.0663 & 0.934 \\
\hline \hline Ergodic & 0.16 & 0.255 & 0.19 & 0.233 & 0.153 \\
\hline \hline
\end{tabular}

Table 17: Metallic Industry. First Order Transition Matrix Average 1984-1990. Chemical Industry

Time Stationarity

\begin{tabular}{|l|c|c|c|c|c|}
\hline \hline $\begin{array}{l}\text { Upper end of } \\
\text { the state }\end{array}$ & 0.19 & 0.395 & 0.750 & 1.51 & $\infty$ \\
\hline 0.19 & 0.879 & 0.117 & 0.0038 & 0.00 & 0.00 \\
\hline 0.395 & 0.107 & 0.753 & 0.137 & 0.0035 & 0.00 \\
\hline 0.750 & 0.0075 & 0.104 & 0.768 & 0.12 & 0.00 \\
\hline 1.51 & 0.00 & 0.0068 & 0.138 & 0.773 & 0.0819 \\
\hline$\infty$ & 0.00 & 0.003 & 0.00 & 0.0776 & 0.919 \\
\hline \hline Ergodic & 0.18 & 0.19 & 0.232 & 0.193 & 0.196 \\
\hline \hline
\end{tabular}


Table 18: Machinery and Equipment Industry. First Order Transition Matrix Average 1984-1990. Machinery and Equipment Industry Time Stationarity

\begin{tabular}{|l|c|c|c|c|c|}
\hline $\begin{array}{l}\text { Upper end of } \\
\text { the state }\end{array}$ & 0.145 & 0.35 & 0.675 & 1.42 & $\infty$ \\
\hline 0.145 & 0.973 & 0.0269 & 0.00 & 0.00 & 0.00 \\
\hline 0.35 & 0.075 & 0.808 & 0.117 & 0.00 & 0.00 \\
\hline 0.67 & 0.00 & 0.06 & 0.832 & 0.105 & 0.00 \\
\hline 1.42 & 0.005 & 0.00 & 0.12 & 0.81 & 0.0652 \\
\hline$\infty$ & 0.00 & 0.000 & 0.00 & 0.13 & 0.870 \\
\hline \hline Ergodic & 0.385 & 0.126 & 0.217 & 0.182 & 0.09 \\
\hline \hline
\end{tabular}

Table 19: Car Industry. First Order Transition Matrix

Average 1984-1990. Car Industry

Time Stationarity

\begin{tabular}{|l|c|c|c|c|c|}
\hline \hline $\begin{array}{l}\text { Upper end of } \\
\text { the state }\end{array}$ & 0.14 & 0.255 & 0.565 & 1.24 & $\infty$ \\
\hline 0.14 & 0.886 & 0.114 & 0.00 & 0.00 & 0.00 \\
\hline 0.255 & 0.0616 & 0.836 & 0.102 & 0.00 & 0.00 \\
\hline 0.565 & 0.00 & 0.062 & 0.846 & 0.092 & 0.00 \\
\hline 1.24 & 0.00 & 0.00 & 0.59 & 0.877 & 0.0637 \\
\hline$\infty$ & 0.00 & 0.000 & 0.00 & 0.066 & 0.934 \\
\hline \hline Ergodic & 0.065 & 0.122 & 0.201 & 0.312 & 0.301 \\
\hline \hline
\end{tabular}




\section{References}

Davis, Steven J., and John Haltiwanger (1990). "Gross Job Creation and Destruction: Microeconomic Evidence and Macroeconomic Implications". NBER Macro Economic Annual. Vol 5: 123- 168.

-_-- (1992). "Gross Job Creation, Gross Job Destruction and Employment Reallocation." Quarterly Journal of Economics. Vol. 107: 819-863.

Davis, Steven J., John Haltiwanger, and Scott Shuh (1994). Gross Job Flows in U.S. Manufacturing. Bureau of the Census. Unpublished.

_-_- (1995). "Small Business and Job Creation: Dissecting the Myth and Reassessing the Facts", Small Business Economics, forthcoming.

Evans, David S. (1987a). "Test of Alternative Theories of Firm Growth", Journal of Political Economy. Vol. 95: 657-674.

-_-- (1987b). "The Relationship between Firm Growth, Size and Age: Estimate for 100 Manufacturing Industries", Journal of Industrial Economics. Vol. 35: 567-581.

Friedman, Milton (1992). "Do Old Fallacies Ever Die?" Journal of Economic Literature. Vol. 30: 2129- 2132.

Geweke, John, Robert C. Marshall, and Gary Zarkin (1986). "Mobility Indices in Continuous Time Markov Chains" Econometrica. Vol. 54: 1407-1423.

Hamermesh, Daniel S. (1993). Labor Demand. Princeton: Princeton University Press.

Konings, Jozeph (1995). "Gross Job Flows and The Evolution of Size in U.K. Establishments." Small Business Economics. Vol. 7: 213-220.

Lamo, Ana. and Reinault Koopmans (1995). "Cross Sectional Firm Dynamics: Theory and Empirical Results from the Chemical Sector." Centre for Economic Performance Discussion paper num 229.

OECD (1994). "Job Gains and Job Losses in Firms", OECD Employment Outlook. Ch.3: $103-166$. 
Quah, Danny (1993a). "Empirical Cross-section Dynamics in Economic Growth." European Economic Review. Vol. 37: 426-434.

---- (1993b). "Galton's Fallacy and tests of the Convergence Hypothesis." The Scandinavian Journal of Economics. Vol. 95: 427-443.

-_-- (1994). "Convergence Empirics Across Economies with (Some) Capital Mobility." Sticerd. Discussion Paper Num. EM/94/275.

R\&P (1995). "A Study on Job Creation and Job Destruction in Europe." Study for the Commission of the European Communities, D.G.V. Unpublished. 